Linguistik Terapan 18 (2) (2021): 139 - 148

Jurnal Linguistik Terapan Pascasarjana

Available online

http://jurnal.unimed.ac.id/2019/index.php/JLT-Unimed

\title{
THE EFFECT OF AUDIO, VIDEO AND MOTIVATION ON STUDENTS' LISTENING COMPREHENSION ACHIEVEMENT
}

\author{
Roudhotul Jannah Panjaitan \\ Zainuddin \\ Rahmad Husein \\ English Applied Linguistic Program \\ Postgraduate Program - Universitas Negeri Medan
}

Diterima Mei 2021; Disetujui Juni 2021; Dipublikasikan Agustus 2021

\begin{abstract}
The objectives of this study were to explain whether : (1) the students' achievement in listening comprehension taught by using video was significantly higher than that taught by audio (2) the students' achievement taught to high motivation significantly was higher than that to students' low motivation? (3) therewas any significant interaction among teaching media (video and audio) and motivation in listening comprehension achievement. The research design is experimental research by using factorial design $2 \times 2$. There were 72 students from MAS YMPI Kota Tanjungbalai as sample of this research. The students were divided into two groups. The first group was treated by using Audio and the second group was treated by using Video. Students' achievement in listening comprehension was measured by using multiple choice tests. The data were analyzed by applying Two-Ways ANOVA. The result revealed that (1) students' listening comprehension achievement taught by using video wassignificantly higher than that taught by using audio with Fobservedwas higher than that Ftable at level significance $\alpha=0.05\left(\mathrm{~F}_{\text {observed }}=155.7>\mathrm{F}_{\text {table }}\right.$ = 3.98). (2) There was significant difference of students achievement in listening comprehension with high motivation was taught by using video was higher than that low motivation by using audio with Fobserved is higher than Ftable at the level significance $\alpha$ $=0.05\left(\mathrm{~F}_{\text {observed }}=93.4>\mathrm{F}_{\text {table }}=3.98\right)$. (3) There was significance interaction among media (audio and video) and students' motivation on students' achievement in listening comprehension with Fobservedwas lower than Ftable at level significance $\alpha=0.05$ $\left(\mathrm{F}_{\text {observed }}=1.2<\mathrm{F}_{\text {table }}=3.98\right)$. Thus, media (audio and video $)$ and students' motivation significantly affect the students' achievement in listening comprehension.
\end{abstract}

Keywords: Audio, Video, Motivation, Listening Comprehension

How to Cite: Jannah Panjaitan, Roudhotul. (2021). The Effect Of Audio, Video And Motivation On Students' Listening Comprehension Achievement. Jurnal Linguistik Terapan Pascasarjana Unimed. 18 (2): 139 - 148. 


\section{INTRODUCTION}

Listening is one of the language skills that should be mastered by students in learning English. Language skills are often categorized as receptive or productive. Speaking and writing are the productive skills. Listening, along with reading, is a receptive skill. Requires a person to receive and understand incoming information. People can listen to and understand things at a higher level than they can produce. Listening is the ability to identify and understand what others are saying including understanding speakers' accent or pronunciation, grammar and vocabulary, and grasping the meaning.

Teaching listening comprehension in the level of Senior High School in Indonesia is considered at the level of advance. Based on syllabus from 2013 Curriculum grade X, The purpose of teaching listening at the tenth grade of senior high schools is to provide the students the ability to understand the variety of ideas (interpersonal, ideational, and textual) which has communicative purposes, texts' structure and certain linguistics features in various oral texts. The listening activities start from the word level, sentence level and meaning based level. Yavuz, etc (2015) claim that the exercise types those early level pupils can be given are repetition which they are only expected to repeat what they hear, asking if what they hear is English or not and to decide if they hear the same or different utterances.Based on Wilson (2010), the students frequently encounter many unknown words, lexical density (short spaces of time between content words, forcing listener to concentrate harder), and complex grammatical structures. In addition, Gilakjani and Sabouri, (2016) also declare that the quality of recorded materials, cultural differences, accent, unfamiliar vocabulary, length and speed of listening are also the aspects that considered as the difficulties in learning listening skill.

The internal factors are come from inside the individual. They cover from the individual students like motivation, attitude, personal practice and study habits. (Brown, 2010). Each of these factors is an individual element of learners' ability to acquire a foreign language but each component also interacts with another.

Media is one of the external factors in influencing listening comprehension achievement. It is important for the teacher to find a suitable media in the listening comprehension teaching to help the students to be more active. There are many kinds of media in teaching listening. The use of media in classroom is proven to be effective as Heinich (2013) states that teaching media can stimulate the students' interest and encourage 
students' participation. Among all the media which are commonly used in teaching and learning one of which that is quite innovative and interesting are audio and video.

Based on the observation conducted in the area, students of Yayasan Madrasah Perguruan Islam Kota Tanjungbalai in grade X MIA1 and X MIA2 have low ability in listening comprehension. They do not have high interest in listening comprehension. It can be proved with their habit to have listening section in the classroom. They hardly catch up the listening production from teacher's voice. It is difficult to comprehend the context of listening. Teacher orally only dictates the sentences to the students. Another negative fact can be discovered from the daily score examination result. It is showed from their achievement last year in the first semester that mostly (68.5) could not get the minimum passing grade $(\mathrm{KKM})$.

\section{METHODOLOGY}

This research, experimental design by using factorial design $2 \times 2$ ways would be used. There were three (3) variables in this research, they were: independent variables: video and audio, attribute variable: motivation and dependent variable: students' achievement in listening comprehension.The population of this study was the first grade of Madrasah Aliyah Swasta (MAS) Yayasan Madrasah Pendidikan Islam (YMPI) Kota Tanjungbalai, Sumatera Utara in academic year 2020/ 2021. The sample in this study were X MIA1 and X MIA2. There were only 72 students which would be devided into two (2) groups. The first $\left(1^{\text {st }}\right)$ group that consisted of 36 students would be given a treatment by using video and the second $\left(2^{\text {nd }}\right)$ group would be treated by using audio.

\section{FINDINGS AND DISCUSSIONS}

The data of the students' achievement in listening comprehension from every interaction between media and students motivation obtained the maximum and minimum scores, mean, standard deviation and variance. The summary of the research data description can be seen in Table 1.

Table 1. Summary of Data Description

\begin{tabular}{ccccccccc}
\hline Statistical Values & A1 & A2 & B1 & B2 & A1B1 & A1B2 & A2B1 & A2B2 \\
\hline $\mathrm{N}$ & 36 & 36 & 36,00 & 36 & 18 & 18 & 18 & 18 \\
Sum & 2567.5 & 2855 & 3067.5 & 2650 & 1412.5 & 1225 & 1602.5 & 1370 \\
Highest Score & 80 & 90 & 95 & 80 & 82.5 & 82.5 & 95 & 85 \\
Lowest Score & 60 & 70 & 80 & 65 & 72.5 & 60 & 85 & 70 \\
Mean & 71.32 & 79.31 & 85.21 & 73.61 & 78.47 & 68.06 & 89.03 & 76.11 \\
Median & 72.5 & 80 & 85 & 75 & 77.5 & 67.5 & 88.75 & 76.25 \\
Mode & 72.5 & 77.5 & 82.5 & 75 & 77.5 & 62.5 & 87.5 & 77.5
\end{tabular}




\begin{tabular}{ccccccccc} 
Std deviation & 4.65 & 4.54 & 3.8 & 4.29 & 2.73 & 5.79 & 3.11 & 4.39 \\
\hline Variance & 21.6 & 20.58 & 14.42 & 18.37 & 7.46 & 33.5 & 9.66 & 19.28 \\
\hline
\end{tabular}

\section{A. Students' Achievement in Listening Comprehension Taught by Using Audio}

Scores of students' achievement in listening comprehension taught by using Audio could be explained that the highest score was 80 and the lowest score was 60 , mean 71.32, variance was 21.60 and standard deviation was 4.65.

Table 2. Frequency Distribution of Students' Achievement in Listening Comprehension Taugh by Using Audio

\begin{tabular}{cccc} 
Class & Interval & Absolute Frequency & Relative Frequency \\
\hline 1 & $60-62$ & 1 & $3 \%$ \\
2 & $63-65$ & 4 & $11 \%$ \\
3 & $66-68$ & 5 & $14 \%$ \\
4 & $69-71$ & 5 & $14 \%$ \\
5 & $72-74$ & 9 & $25 \%$ \\
6 & $75-77$ & 8 & $22 \%$ \\
7 & $78-80$ & 4 & $11 \%$ \\
\hline \multicolumn{5}{c}{ TOTAL } & 36 & $100 \%$ \\
\hline
\end{tabular}

Based on The table 2 , it could be described that the students' scores werw divided into three categories : (1) students who got average score were 5 students or $14 \%$, (2) students who got above average score were 21 students or $58 \%$, (3) students who got below average score were 10 students or $28 \%$.

\section{B. Students' Achievement in Listening Comprehension Taught by Using Video}

The scores of students' achievement in listening comprehension taught by using video could be explained that the highest score was 90, mean 79.31, variance was 20.58 , and standard deviation was 4.5 .

Table 3. Frequency Distribution of Students' Achievement in Listening Comprehension Taught by Video

Class Interval Absolute Frequency Relative Frequency

$1 \quad 70-72$

1

$3 \%$ 


\begin{tabular}{cccc}
2 & $73-75$ & 7 & $19 \%$ \\
3 & $76-78$ & 9 & $25 \%$ \\
4 & $79-81$ & 9 & $25 \%$ \\
5 & $82-84$ & 4 & $11 \%$ \\
6 & $85-87$ & 3 & $8 \%$ \\
7 & $88-90$ & 3 & $8 \%$ \\
\hline & Total & $\mathbf{3 6}$ & $\mathbf{1 0 0 \%}$ \\
\hline
\end{tabular}

Based on the Table 3 , it could be described that students' scores was divided into three categories : (1) students who got average score were 9 students or $25 \%$, (2) students who got above average score were 10 students or $27 \%$, (3) students who got below average score were 17 students or $47 \%$.

\section{Students' Achievement in Listening Comprehension with High Motivation}

Score of students' achievement in Listening Comprehension with high motivation could be explained that the highest score was 95 and the lowest score was 80, mean 85.21, variance was 14.42 and standard deviation was 3.80 .

Table 4. Frequency Distribution of Students' Achievement in Listening Comprehension with High Motivation

\begin{tabular}{cccc} 
Class & Interval & $\begin{array}{c}\text { Absolute } \\
\text { Frequency }\end{array}$ & $\begin{array}{c}\text { Relative } \\
\text { Frequency }\end{array}$ \\
\hline 1 & $80-82$ & 5 & $14 \%$ \\
2 & $83-85$ & 17 & $47 \%$ \\
3 & $86-88$ & 9 & $25 \%$ \\
4 & $89-91$ & 2 & $6 \%$ \\
5 & $92-94$ & 2 & $6 \%$ \\
6 & $95-97$ & 1 & $3 \%$ \\
\hline & TOTAL & $\mathbf{3 6}$ & $\mathbf{1 0 0 \%}$ \\
\hline
\end{tabular}

Based on the Table 4 , it could be described that students' score was divided into three categories : (1) students who got average score were 17 students or $47 \%$, (2) students who got above average score were 14 students or $40 \%$, (3) students who got below average score were 5 students or $14 \%$.

\section{Students' Achievement in Listening Comprehension with Low Motivation}

Score of students' achievement in Listening Comprehension with low motivation could be explained that the highest score was 80 and the lowest score was 65 , mean 73.61, variance was 18.37 and standard deviation was 4.29. 
Table 5. Frequency Distribution of Students' Achievement in Listening Comprehension with Low Motivation

\begin{tabular}{cccc}
\hline Class & Interval & $\begin{array}{c}\text { Absolute } \\
\text { Frequency }\end{array}$ & $\begin{array}{c}\text { Relative } \\
\text { Frequency }\end{array}$ \\
\hline 1 & $65-67$ & 3 & $8 \%$ \\
2 & $68-70$ & 7 & $19 \%$ \\
3 & $71-73$ & 6 & $17 \%$ \\
4 & $74-76$ & 10 & $28 \%$ \\
5 & $77-79$ & 6 & $17 \%$ \\
6 & $80-82$ & 4 & $11 \%$ \\
\hline & Total & $\mathbf{3 6}$ & $\mathbf{1 0 0 \%}$ \\
\hline
\end{tabular}

Based

it could be described that students' score was divided into three categories : (1) students who got average score were 10 students or $28 \%$, (2) students who got above average score were 10 students or $28 \%$, (3) students who got below average score were 16 students or $44 \%$.

\section{E. Students' Achievement in Listening Comprehension with High Motivation Taught by Audio}

Score of students' achievement in Listening Comprehension with high motivation and taught by using audio could be explained that the highest score was 82.50 and the lowest score was 72.50, mean 78.47, variance was 7.46 and standard deviation was 2.73 .

Table 6. Frequency Distribution of Students' Achievement in Listening Comprehension with High Motivation and Taught by Using Audio

\begin{tabular}{|c|c|c|c|c|c|}
\hline & Class & Interval & $\begin{array}{l}\text { Absolute } \\
\text { Frequency }\end{array}$ & $\begin{array}{l}\text { Relative } \\
\text { Frequency }\end{array}$ & \multirow{8}{*}{$\begin{array}{l}\text { on the Table } 6 \\
\text { described that } \\
\text { score was }\end{array}$} \\
\hline \multirow{7}{*}{$\begin{array}{l}\text {, it could be } \\
\text { students' }\end{array}$} & 1 & $73-74$ & 1 & $6 \%$ & \\
\hline & 2 & $75-76$ & 2 & $11 \%$ & \\
\hline & 3 & $77-78$ & 7 & $39 \%$ & \\
\hline & 4 & $79-80$ & 5 & $28 \%$ & \\
\hline & 5 & $81-83$ & 3 & $17 \%$ & \\
\hline & & Total & 18 & $100 \%$ & \\
\hline & & & & & \\
\hline
\end{tabular}




\section{F. Students' Achievement in Listening Comprehension with Low Motivation Taught by Audio}

Score of students' achievement in Listening Comprehension with high motivation and taught by using audio could be explained that the highest score was 82.50 and the lowest score was 60, mean 68.06, variance was 33.50 and standard deviation was 5.79.

Table 7. Frequency Distribution of Students' Achievement in Listening

Comprehension with Low Motivation and Taught by Using Audio

\begin{tabular}{cccc} 
Class & Interval & $\begin{array}{c}\text { Absolute } \\
\text { Frequency }\end{array}$ & $\begin{array}{c}\text { Relative } \\
\text { Frequency }\end{array}$ \\
\hline 1 & $60-64$ & 5 & $28 \%$ \\
2 & $65-69$ & 5 & $28 \%$ \\
3 & $70-74$ & 6 & $33 \%$ \\
4 & $75-79$ & 1 & $6 \%$ \\
5 & $80-84$ & 1 & $6 \%$ \\
\hline & Total & $\mathbf{1 8}$ & $\mathbf{1 0 0 \%}$ \\
\hline
\end{tabular}

Based on the Table 7 , it could be described that students' score was divided into three categories : (1) students who got average score were 5 students or $28 \%$, (2) students who got above average score were 8 students or $45 \%$, (3) students who got below average score were 5 students or $28 \%$

\section{G. Students' Achievement in Listening Comprehension with High Motivation Taught by Video}

Score of students' achievement in Listening Comprehension with high motivation and taught by using video could be explained that the highest score was 95 and the lowest score was 85 , mean 89.03 , variance was 9.66 and standard deviation was 3.11

Table 8. Frequency Distribution of Students' Achievement in Listening

Comprehension with High Motivation and Taught by Using Video

\begin{tabular}{cccc} 
Class & Interval & $\begin{array}{c}\text { Absolute } \\
\text { Frequency }\end{array}$ & $\begin{array}{c}\text { Relative } \\
\text { Frequency }\end{array}$ \\
\hline 1 & $85-86$ & 4 & $22 \%$ \\
2 & $87-88$ & 5 & $28 \%$ \\
3 & $89-90$ & 4 & $22 \%$
\end{tabular}




\begin{tabular}{cccc}
4 & $91-92$ & 0 & $0 \%$ \\
5 & $93-95$ & 5 & $28 \%$ \\
\hline & Total & $\mathbf{1 8}$ & $\mathbf{1 0 0 \%}$ \\
\hline
\end{tabular}

Based on the Table 8 , it could be described that students' score was divided into three categories : (1) students who got average score were 4 students or $22 \%$, (2) students who got above average score were 5 students or $28 \%$, (3) students who got below average score were 9 students or $50 \%$.

\section{H. Students' Achievement in Listening Comprehension with Low Motivation Taught by Video}

Score of students' achievement in Listening Comprehension with high motivation and taught by using video could be explained that the highest score was 85 and the lowest score was 70, mean 76.11, variance was 19.28 and standard deviation was 4.39.

Table 9. Frequency Distribution of Students' Achievement in Listening Comprehension with High Motivation and Taught by Using Video

\begin{tabular}{cccc} 
Class & Interval & $\begin{array}{c}\text { Absolute } \\
\text { Frequency }\end{array}$ & $\begin{array}{c}\text { Relative } \\
\text { Frequency }\end{array}$ \\
\hline 1 & $70-72$ & 3 & $17 \%$ \\
2 & $73-75$ & 6 & $33 \%$ \\
3 & $76-78$ & 4 & $22 \%$ \\
4 & $79-81$ & 3 & $17 \%$ \\
5 & $82-85$ & 2 & $11 \%$ \\
\hline & Total & $\mathbf{1 8}$ & $\mathbf{1 0 0 \%}$ \\
\hline
\end{tabular}

Based on the Table 9, it could be described that students' score was divided into three categories : (1) students who got average score were 4 students or $22 \%$, (2) students who got above average score were 5 students or $28 \%$, (3) students who got below average score were 9 students or $50 \%$.

\section{Significant Interaction Between Media and Students' Motivation on Listening Comprehension Achievement}

The statistical hypothesis:

$\mathrm{Ho}_{3}: \mu \mathrm{A} \times \mu \mathrm{B}_{1=0}$

$\mathrm{Ha}_{3}: \mu \mathrm{A} \times \mu \mathrm{B} \neq 0$ 
The summary of ANOVA calculation in table 4.16 indicated that $\mathrm{F}_{\text {observed }}=1.2$ and $F_{\text {table }}=3.98$ and the result indicated that $F_{\text {observed }}<\mathrm{F}_{\text {table }}$ so null hypothesis $\left(\mathrm{H}_{0}\right)$ has been rejected and it can be concluded that the third hypothesis of this research which stated that there is interaction between audio, video, and learning motivation to the students' achievement in listening comprehension is really true. Based on the hypothesis testing of the research, it seen in interaction in Figure 1

Estimeted Marginal Means of Listening Comprehension

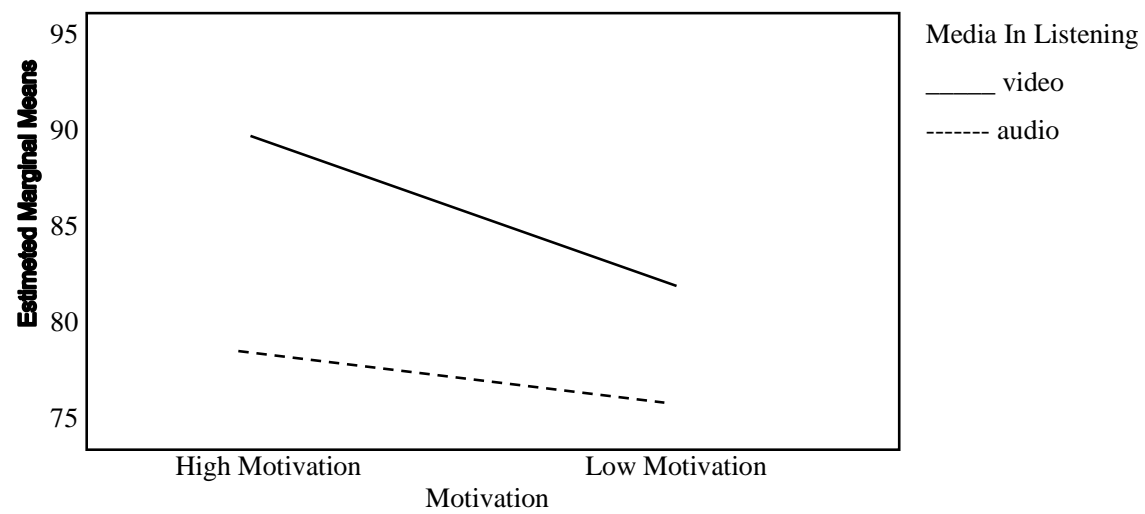

Figure 1. The Interaction of Listening Comprehension and Students' Motivation

A1B1 = Audio Media with High Motivation

A2B2 = Video Media With Low Motivation

From the Figure 1, the description between the line of Audio and Video media shows that the interaction pattern between media and students' motivation is not sequal but cross each other based on research findings listening media and students' motivation have important affect to increase students' achievement in listening comprehension. Video more suitable with the students with high motivation and audio with students have low motivation.

\section{CONCLUSIONS}

Based on the data analysis and hypothesis testing, it concluded:

1. The first hypothesis shown that Fobserved > Ftable, so null hyphothesis (H0) has been rejected and it can be concluded that the research which stated that the students' achievement in listening comprehension taught by using video was significantly higher than that taught by using audio is really true. It can be concluded that both audio and video significantly affect the students' achievement in listening comprehension. 
2. The second hypothesis shown that Fobserved > Ftable, so null hypothesis (H0) has been rejected and it can be concluded that the research which stated that the students' achievement in listening comprehension with high motivation is higher than those with low motivation is really true. It can be conluded that the students have high motivation have higher achievement that the students with low motivation and level of students' motivation affect the students' ability in listening comprehension.

3. The summary of ANOVA indicated that Fobserved > Ftable, so null hypothesis (H0) has been rejected and it can be concluded that the third hypothesis of this research which stated that there is interaction between audio, video and learning motivation to the students achievement in listening comprehension is really true. It can be concluded that teaching media and learning motivation have good impact students' achievement on listening comprehension.

\section{REFERENCES}

Ary Donal, Lucy Cheser Jacobs, Chris Sorensen, Asghar Razavieh. 2010. Introduction to Research in Education. Wadsworth: Cengage Learning

Brown, Douglas. 2010. Principles of Language Learning and Teaching. Indiana: Prentice Hall.

Gilakjani, Pourhosein, A., and Ahmadi, S. M. 2011. The Relationship between L2 Reading Comprehension and Schema Theory: A Matter of Text Familiarity. International Journal of Information and Education Technology, 1(2), 142-149.

Heinich, R., et. al. 2013. Instructional Media and Technologies for Learning. New Jersey: Prentice Hall, Englewood Cliffs.

Kavaliauskiene, G. 2011. Podcasting: A Tool for Improving Listening Skills. Retrieved February 24, 2012 from: The Journal of Teaching English with Technology (TEwT), Vol. 8 issue 4, 2008.

Wilson, HF 2010. Passing propinquities in the multicultural city: The everyday encounters of bus passengering. Environment and Planning A 43(3): 634.

Yavuz, Fatih and Hande Yilmaz. 2015. The Problems Young Learners Encounter during Listening Skills. Procedia: Social and Behavioral Sciences 197. Page 2014620150. Science Direct. 